\title{
RESEARCH ON MENTAL HEALTH INTERVENTION OF COLLEGE STUDENTS BASED ON MUSIC THERAPY
}

\author{
PESQUISA SOBRE INTERVENÇÃO NA SAÚDE MENTAL DE ESTUDANTES UNIVERSITÁRIOS COM BASENA \\ TERAPIAMUSICAL
}

\section{INVESTIGACIÓN SOBRE LA INTERVENCIÓN EN SALUD MENTAL DE ESTUDIANTES UNIVERSITARIOS BASADA EN MÚSICA}

\author{
Yuegiao Liu' ${ }^{\text {(ID }}$ \\ (Public health Education) \\ 1. School of Music, Nanshan \\ College, Yantai, Yantai, \\ Longkou-265700, China.
}

\section{Correspondence:} Antai, Longkou-265700, China. ota69379@sina.com

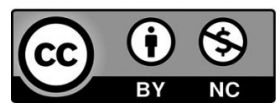

\begin{abstract}
Although contemporary college students are in an era of stable environment and rich economy, the society has stricter requirements on their study and work. College students face various pressures from themselves and society, and psychological problems emerge one after another. From the practice abroad, music therapy itself has fully demonstrated the alleviation and improvement of people's mental health. Music is a part of human life, and its penetration and influence on human behavior is unparalleled by other cultural forces. Music does not only give people the enjoyment of beauty, but also influences people's mind, body and behavior through multiple psychological and physiological functions. The use of music therapy can better improve and optimize the ability of college students to eliminate bad emotions, so as to help students develop healthy a psychological state and establish a correct outlook on life and values. Based on this, this study explores the significance of contemporary college students' music therapy on mental health, and puts forward the orientation and implementation ways of college students' mental health education.
\end{abstract}

Keywords: College students; Psychological problems; Music therapy.

\section{RESUMO}

Embora os universitários contemporâneos estejam em uma era de ambiente estável eeconomia rica, a sociedade tem exigências mais rigorosas em seu estudo e trabalho. Os estudantes universitários enfrentam várias pressões de si mesmos e da sociedade, e problemas psicológicos emergem um após o outro. Desde a prática no exterior, a própria terapia musical tem demonstrado plenamente o alívio e a melhoria da saúde mental das pessoas. A música faz parte do estilo de vida humano, e sua penetração e influência no comportamento humano é incomparável por outras forças culturais. A música não só dá às pessoas o prazer da beleza, mas também influencia a mente, o corpo e o comportamento das pessoas através de múltiplas funções psicológicas e fisiológicas. O uso da terapia musical pode melhorar e otimizar melhor a capacidade dos estudantes universitários de eliminar as emoções ruins, de modo a ajudá-los a desenvolver um estado psicológico saudável e estabelecer uma perspectiva correta sobre sua vida e seus valores. Com base nisso, este trabalho explora a relevância da terapia musical contemporânea entre estudantes universitários sobre sua saúde mental, e avança as formas de orientação e implementação da educação de saúde mental desses indivíduos.

Descritores: Estudantes universitários; problemas psicológicos; terapia musical.

\section{RESUMEN}

Aunque los estudiantes universitarios contemporáneos se encuentran en una época de ambiente estable y economía rica, la sociedad tiene requisitos más estrictos respecto a sus estudios y trabajo. Los estudiantes universitarios enfrentan diversas presiones de símismos y de la sociedad, y los problemas psicológicos surgen uno tras otro. Desde la práctica en el extranjero, la musicoterapia en sí ha demostrado el alivio y la mejora de la salud mental de las personas. La música es parte del estilo de vida humano y su penetración e influencia en el comportamiento humano no tiene paralelo con otras fuerzas culturales. La música no solo brinda a las personas el disfrute de la belleza, sino que también influye en la mente, el cuerpo y el comportamiento de las personas a través de múltiples funciones psicológicas y fisiológicas. El uso de la musicoterapia puede mejorar y optimizar la capacidad de los estudiantes universitarios para eliminar las malas emociones, a fin de ayudarlos a desarrollar un estado psicológico saludable y establecer una perspectiva correcta de la vida y sus valores. Con base en esto, este trabajo de estudio explora la importancia de la musicoterapia en la salud mental de los estudiantes universitarios contemporáneos y presenta las formas de orientación e implementación de la educación en salud mental de dichos estudiantes.

Descriptores: Estudiantes universitarios; problemas psicológicos; terapia musical. 


\section{INTRODUCTION}

With the acceleration of people's life rhythm, the standard of living is becoming richer, and meeting people's material needs is no longer the top priority. People are looking forward to spiritual abundance. Looking forward, many developed countries have improved people's satisfaction. ${ }^{1}$ For college students whose psychological state is not yet mature and stable, the rapid development of science and technology, the fierce competition of society, the acceleration of life rhythm, the impact of ideas and concepts, increasing employment pressure, economic pressure, and many uncertainties are all College students have a strong sense of urgency and pressure When language counseling is helpless, treatment can be implemented through music experience, music behavior, and music experience. Music not only gives people the enjoyment of beauty, but also affects the mind, body and behavior of people through psychological and physical multiple actions. At present, there are still some problems in the application of music therapy in the psychological health education of college students, including the lack of attention to music therapy, the lack of teachers and advanced technology, etc. ${ }^{2}$ Music therapy itself has fully demonstrated the relief and improvement of people's mental health from foreign practice. Through reasonable music therapy, it can better change the overall pessimism of college students'anxiety, tension and employment pressure. In order to meet the development needs of all aspects of society, make colleges and universities play their own value in talent delivery, and ensure the comprehensive improvement of students'abilities and quality, it is necessary to pay attention to the balanced development of students' physical and mental aspects.

Due to the social pressure and future employment pressure, the mental health problems of students are becoming increasingly prominent. The practice of music therapy can improve students' perceptual experience and rational cognition. With the improvement of social and cultural level and the acceleration of life rhythm, music has gradually expanded its application scope from simple appreciation, and more and more people accept the idea that music can keep health, recover and treat a variety of diseases. For the freshmen who have just entered the University, everyone is facing a new world, and everything has to be done again. No matter it is interpersonal relationship or learning environment, they must learn to study in the new environment, learn to deal with people, and learn how to live. Music education can alleviate the psychological pressure of college students by strengthening their cultural connotation and aesthetic ability. Traditional psychotherapy takes language as the medium and emphasizes the rational role of human beings. It advocates that the purpose of changing bad emotions is to correct the irrational cognitive concepts in the minds of visitors. The use of slow music rhythm and good atmosphere can help students gradually form a kind of self perception and spiritual pleasure in a harmonious environment, so that they can really receive reasonable treatment in a relaxed and comfortable environment. ${ }^{3}$

Music therapy is a new, cross-edge discipline that integrates music, medicine and psychology. With the development of music therapy specialization, music therapy is widely used in the fields of medicine, psychology and special education, and has achieved many remarkable therapeutic effects. College students are eager to be accepted and understood by others, but due to the lack of social skills or other aspects of personality sensitivity, if this aspect of interpersonal communication cannot be handled in time, it often brings psychological anxiety and burden to college students. College music appreciation teaching should not only cultivate music appreciation ability, but also further cultivate and shape the healthy psychology of college students. Although most ordinary colleges and universities set up psychological counseling institutions, teach college students psychology, mental health care and other courses, but they are far from meeting the requirements of college students for mental health education. The use of music therapy can better improve and optimize the ability of college students to resolve their bad emotions, thereby helping college students cultivate healthy psychology, establish a correct outlook on life and values, and achieve a good and healthy personality. ${ }^{4}$ Healthy psychology can not only escort the normal study and life of college students, but also play an important role in their future development and career prospects. Based on this, this article explores the significance of contemporary college students' music therapy to mental health, and proposes the positioning and implementation of college students' mental health education.

\section{Intervention Methods of Music Therapy on College Students' Mental Health}

\section{Creating campus music atmosphere}

Music therapy is suitable for the school's educational situation. It has a very important role in preventing and treating students' physical and mental diseases, debugging bad emotions, cultivating college students' healthy emotions and cooperative spirit, promoting college students'self-expression, and developing innovative thinking and innovative abilities. Campus atmosphere is one of the main factors that affect the physical and mental health of students. Therefore, maintaining the enthusiasm of the campus environment is an important content for relevant personnel. The campus culture of colleges and universities is conducive to the shaping of students' character and temperament, allowing students to develop in a balanced manner in body and mind. Campus culture maintains a certain degree of enthusiasm, is conducive to students to establish the correct three views and learning views, and promote students to achieve comprehensive development. The shaping of music culture can also enable students to perfect their personality in a relaxed and enjoyable process. While universities are fully aware of the importance of music therapy to the mental health of college students, they should fully implement all aspects of this work. ${ }^{5}$ In order to give play to the actual role of music therapy, colleges and universities should also pay attention to the effective shaping of campus culture while providing support in resources. In the implementation of the educational mechanism of music art, it is necessary to further publicize and promote music therapy, so that college students can also realize the importance of music therapy and lay the foundation for the development and application of psychotherapy. In the application of music therapy, it should not be in the form. According to tradition, it should continue to advance with the times, and promote the diversified development of music therapy education according to the preference of contemporary students for music.

\section{Strengthening the cultivation of students' aesthetic ability of music art}

Music aesthetics and cultural connotation are important training contents. According to the needs of students in all aspects, targeted education and music therapy interventions should be carried out to promote students to actively participate in creation. A survey of common psychological problems of college students shows that interpersonal communication disorder has become the most prominent psychological problem of college students, which is mainly manifested in emotional disorders, cognitive disorders and personality disorders. The biggest advantage of music therapy is to use the form of music entertainment to solve the psychological problems of patients with the psychological benefits of interactive behaviors. ${ }^{6}$ While carrying out music therapy, psychological teaching arrangements need to be targeted and purposeful. In this process, if students do not have a certain musical aesthetic ability, they cannot understand the connotation of music, then music therapy is in vain. The full implementation of music therapy and music education requires 
an understanding of students' specific mental health, including what interests and preferences college students possess. The development of music therapy should be in accordance with music education to formulate corresponding plans and goals. At present, most of the professional teachers with psychotherapy qualifications do not have high-quality music aesthetic ability, so it is necessary to hire comprehensive talents in this field to lead the construction of this work and form a high-quality teacher team. In the promotion of music therapy, schools need to strengthen publicity, improve students' correct understanding of music therapy and music education, change students' prejudice against music education, and actively participate in various music activities.

Through various forms of music activities, music education can enable college students to be relieved of psychological pressure. Through the process of music appreciation, it can promote the balanced development of the brain and improve the ability of image thinking and abstract thinking. Restricted by productivity and the level of understanding, human beings are only concerned about how to adapt and conquer nature, maintain their own survival, and treat health and life as well. Music as a common spiritual food for human beings in music education activities can make people obtain pleasure and beauty in spirit. The setting of the course content and the application of teaching methods should also be constantly enriched, and the teaching content should be contemporary and targeted according to the characteristics of the development of the times. Only by ensuring that it has strong interpersonal skills can we get more like-minded teachers and friends.

\section{CONCLUSIONS}

In recent years, college students' psychological problems have become more and more prominent, which has an adverse impact on their personality shaping and development, so college students' psychological health education is particularly important. Education needs to start from students'actual needs, understand students'real psychological barriers and solve them in a targeted way. Music therapy has obvious advantages in this respect. As a kind of psychotherapy, music therapy is applied to all aspects of people's lives, including mental health education for college students. Music therapy has become a widely concerned psychotherapy method, which has achieved good intervention effect in the mental health education of college students in practice. Through the analysis results, it can be seen that music therapy can effectively improve the mental health level of college students, aiming at the mental health status of students, the overall situation is good. In order to carry out this work effectively, we should make clear the mental health problems of college students, carry out music education more pertinently, improve students' personality and promote their all-round development in the process. Music therapy should be closely combined with psychological health counseling for college students, and applied to all aspects of college students' school and life.

The author declare no potential conflict of interest related to this article

AUTHORS' CONTRIBUTIONS: The author has completed the writing of the article or the critical review of its knowledge content. This paper can be used as the final draft of the manuscript. Every author has made an important contribution to this manuscript. Yueqiao Liu: writing and execution.

\section{REFERENCES}

1. Chen XJ, Leith H, Aar LE, Manger T, Gold C. Music therapy for improving mental health problems of offenders in correctional settings: systematic review and meta-analysis. Journal of Experimental Criminology. 2016; 12(2):209-228.

2. Blais-Rochette $C$, Miranda D. Music-evoked autobiographical memories, emotion regulation, time perspective, and mental health. Musicae entiae. 2016; 20(1):26-52

3. Lee IM, Shiroma EJ, Lobelo F, Puska P, Blair SN, Katzmarzyk PT, et al. Effect of physical inactivity on major non-communicable diseases worldwide: an analysis of burden of disease and life expectancy. Lancet. 2012; 380(9838):219-29.
4. Heinonen I, Kalliokoski K, Hannukainen JC, Duncker DJ, Nuutila P, Knuuti J. Organ-specific physiological responses to acute physical exercise and long-term training in humans. Physiology (Bethesda). 2014; 29(6):421-36.

5. Terra R, Silva SA, Pinto VS, Dutra PM. Effect of exercise on immune system: response, adaptation and cell signaling. Rev Bras Med Esporte. 2012; 18(3):208-14.

6. Bercier M L, Maynard B R. Interventions for Secondary Traumatic Stress With Mental Health Workers: A Systematic Review. Research on Social Work Practice. 2014; 25(1):81-89. 